\title{
First documented presence of Galeocerdo cuvier (Péron \& Lesueur, 1822) (ELASMOBRANCHII, CARCHARHINIDAE) in the Mediterranean basin (Libyan waters)
}

\author{
Ibrahim M. Tobuni ${ }^{1}$, Ben-Abdallah R. Benabdallah' ${ }^{1}$, Fabrizio Serena ${ }^{2,3}$ and Esmail A. Shakman ${ }^{1 *}$
}

\begin{abstract}
One male and one female specimen of tiger shark, Galeocerdo cuvier (Péron \& Lesueur, 1822), were accidentally caught by a drifting longline for swordfish in the south Mediterranean (Libyan waters). This finding confirms beyond any doubt that the tiger shark may be encountered in the waters of the Mediterranean Sea. Although records of this species has previously been reported, the information is partial or dubious, due to the lack of a description of the individuals found or the uncertain provenance of preserved material. Our finding confirms the record of this species in the southern part of the Mediterranean basin. Images, as well as morphometrics and information on stomach contents are given. Based on the size of the individuals, it is considered that the two specimens were born recently, presumably inside the Mediterranean Sea and likely close to the area where the individuals were found.
\end{abstract}

Keywords: Tiger shark, Galeocerdo cuvier, Carcharhinidae, Mediterranean Sea

\section{Background}

On 7th January 2015, two juvenile specimens, one male and one female of Galeocerdo cuvier (Péron \& Lesueur, 1822) (tiger shark) were caught in the Libyan waters north east of Tripoli on the west part of the Gulf of Sidra (Fig. 1). Tiger shark is a species not usually considered resident in the Mediterranean basin. In line with this, the first two records of G. cuvier, one from Malaga, Spain (Pinto de la Rosa, 1994) and the second from Sicily, Italy (Celona, 2000) have always been considered doubtful, being based solely on the description of the recovered jaws and no reports of live individuals (Serena, 2005).

Our report is the first tiger shark record documented by photographic evidence, in the Mediterranean Sea. The new findings, in this particular case of two recently born individuals, may contribute to addressing the question of whether the presence of the tiger shark can be considered occasional (as vagrant or isolated), or proof of its stable occurrence in the region.

* Correspondence: shugmanism@yahoo.com

'Zoology Department, Tripoli University, Tripoli, Libya

Full list of author information is available at the end of the article
Tiger sharks belong to the Family of CARCHARHINIDAE Jordan \& Evermann, 1896. This species can be considered circumglobal, found at all latitudes excluding Polar Regions. They generally live in warm, temperate and tropical seas and are considered vagrant in the Eastern North Atlantic (Ebert \& Stehmann, 2013) including the Mediterranean Sea (Golani et al. 2002). Tiger shark normally resides further south; including the Azores, Morocco and Canary Islands as far as the Ghana coasts, but it is probable that the species has a wider distribution range in the area. It is also present from the coast of the U.S.A. stretching to Uruguay, including the Gulf of Mexico and Caribbean islands and in the Pacific and Indian oceans and Red Sea (Compagno, 1984; Randall, 1992; Bonfil \& Abdallah, 2004; Ebert \& Stehmann, 2013).

The maximum reported size of the tiger shark is $740 \mathrm{~cm}$ in total length (TL) and $3110 \mathrm{~kg}$ (Fourmanoir, 1961). However, tiger sharks are generally not longer than $500 \mathrm{~cm}$ in TL. The tiger shark is the only viviparous carcharhinid shark to exhibit internal incubator that does not develop a yolk-sac placenta (Bram et al., 2005); it is able to produce one of the larger litter sizes with 


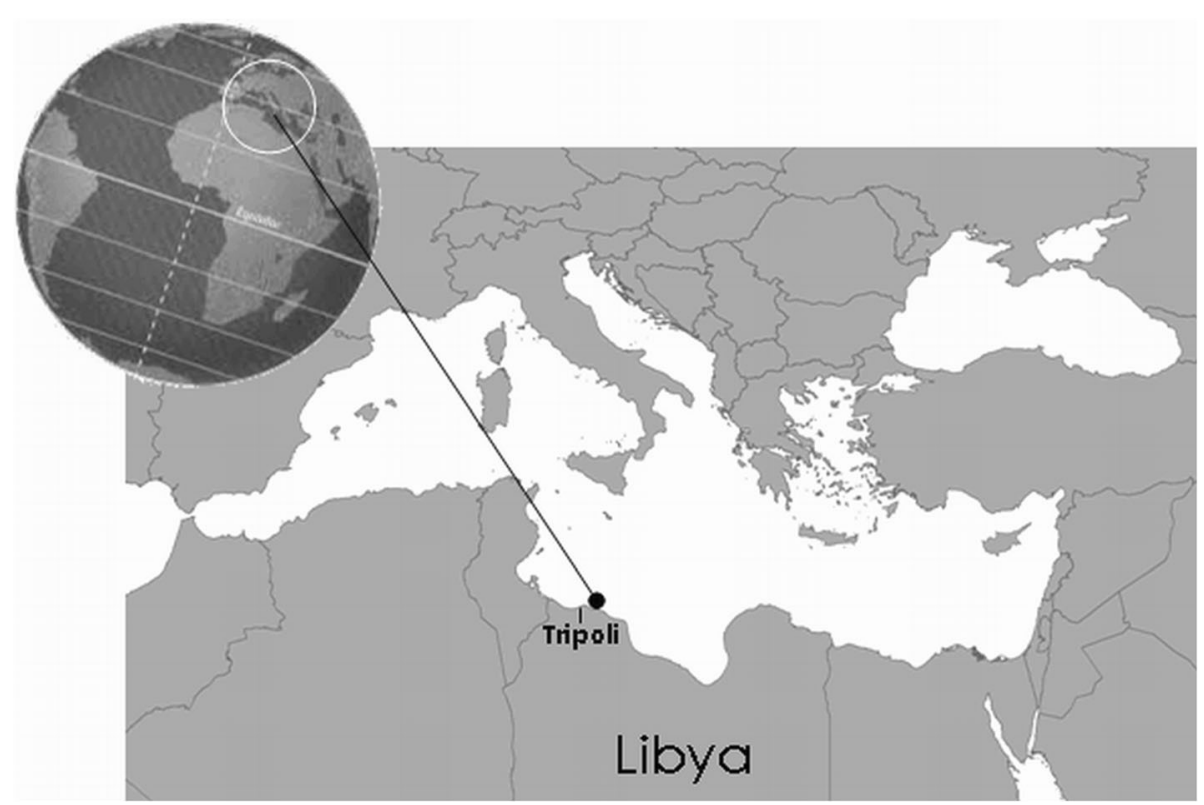

Fig. 1 Map of the Mediterranean Sea and location where the two specimens of Galeocerdo cuvier were caught. The temperature of the water was $13{ }^{\circ} \mathrm{C}$

10-82 young per litter (Tester, 1969; Bass et al., 1975; Simpfendorfer, 1992) with a gestation period between 12 to 16 months in the Northern Hemisphere (Clark \& von Schmidt, 1965). Mating normally occurs in the spring and pupping takes place throughout spring and early summer, usually from April to June. Size at birth ranges between 46 and $90 \mathrm{~cm}$ TL (Compagno, 1984; Randall, 1992; Simpfendorfer, 1992).

\section{Materials and methods}

The tiger shark specimens were caught by Tripoli fishers using artisanal drifting longlines baited with sardines in order to target swordfish. This kind of gear, locally named "bringali sayeb", fish between 10-500 $\mathrm{m}$ in the water column, and is especially utilized by "mator" boats. These vessels have an average power of $214,86 \mathrm{~kW}$ and range in length from 5 to over $18 \mathrm{~m}$ (12 $\mathrm{m}$ on average). In the early 2000s, mator boats constituted the $28 \%$ of the 1800 artisanal fishing boats operating in Libya. Only few mator boats target swordfish (Lamboeuf, 2000). The longline gear is made of a main monofilament (Ø 2-3 mm) of about $14 \mathrm{~km}$ long. One double line snood, consisting of a monofilament $(\varnothing 1.3 \mathrm{~mm}$ ) of $1.5 \mathrm{~m}$ with hooks (size number 01 ), is connected to the main line every $50 \mathrm{~m}$. Every 5 hooks a float is connected the main line by a monofilament $3.5 \mathrm{~m}$ long.

The two tiger sharks caught are documented by pictures taken in the laboratory of the University of Tripoli. In this report, for chondrichthyan taxonomy and nomenclature, the guidelines in Serena (2005), Ebert et al., (2013) and Eschmeyer et al., (2016) were followed. The morphometric measurements shown in Table 1 refer to MEDLEM protocol format (Serena et al., 2006). The stomach content was analyzed in order to identify the food composition (Table 2). Examined material was preserved in formalin $10 \%$ and individuals stored in the collection of the Zoological Museum of Tripoli University with the following code: (ZST, FISH0010; FISH0011). The specimens are available for inspection on request.

\section{Results}

The two juvenile specimens of G. cuvier, one male and one female, were caught at $33^{\circ} 03,710$ Latitude North013 44,529 Longitude Est off Gasr Garabulli, at a depth of $180 \mathrm{~m}$, using artisanal drifting longlines for swordfish Xiphias gladius as target and with Thunnus alalunga, Carcharhinus plumbeus, Isurus oxyrinchus juv. and Pteroplatytrygron violacea as by catch (Fig. 1). The total lengths of the individuals were $95.8 \mathrm{~cm}$ and $97.4 \mathrm{~cm}$ for the male and female respectively (Fig. 2). Both specimens had a large head with short and blunt snouts, large mouths, long upper labial furrows that go beyond the eye lines, large spiracles and small nostrils (Fig. 3). The eyes were fairly large without posterior notches. The first dorsal fin origin was above the pectoral fin inner margins in both specimens. The interdorsal ridge was present and prominent; the body part of the specimens analyzed behind the pectoral fins was, in both cases, rather thin with small keels on the caudal peduncles. The upper pre-caudal pits were transverse and semilunar. The caudal fins were slender with acutely pointed tips. Along the body, including the fins, characteristic bold dark and 
Table 1 Morphometric measurements for tiger Shark Galeocerdo cuvier caught in the Libyan coasts

\begin{tabular}{|c|c|c|c|}
\hline Measurements & & Female & Male \\
\hline Total length & TOT & 97.4 & 95.8 \\
\hline Fork length & FOR & 71.3 & 69.0 \\
\hline Trunk length & TL & 28.0 & 27.8 \\
\hline Precaudal tail & PCT & 18.0 & 17.7 \\
\hline Percaudal length & PRC & 64.8 & 64.7 \\
\hline Presecond dorsal length & PD2 & 54.1 & 53.8 \\
\hline Prefirst dorsal length & PD1 & 24.7 & 24.6 \\
\hline Head length & $\mathrm{HDL}$ & 19.0 & 18.8 \\
\hline Prebranchial length & $P G L$ & 14.0 & 13.5 \\
\hline Preorbital length & POB & 5.2 & 5.0 \\
\hline Prepectoral length & PP1 & 17.1 & 16.9 \\
\hline Prepelvic length & PP2 & 42.4 & 42.3 \\
\hline Preanal length & PAL & 52.0 & 51.5 \\
\hline Interdorsal space & IDS & 22.8 & 22.5 \\
\hline Eye length & EYL & 2.0 & 2.0 \\
\hline Eye height & EYH & 1.6 & 1.6 \\
\hline Prenarial & PRN & 1.8 & 1.7 \\
\hline Preoral length & POR & 4.1 & 4.0 \\
\hline Intergill length & ING & 5.0 & 5.1 \\
\hline Pectoral-fin length & P1L & 12.1 & 11.7 \\
\hline Pectoral-base length & P1B & 4.6 & 4.6 \\
\hline Pectoral-inner margin & P11 & 4.2 & 4.1 \\
\hline 1st dorsal anterior margin & D1A & 10.8 & 10.7 \\
\hline 1st dorsal base length & $\mathrm{D} 1 \mathrm{~B}$ & 7.8 & 7.5 \\
\hline 1st dorsal height & $\mathrm{D} 1 \mathrm{H}$ & 7.8 & 7.6 \\
\hline Dorsal caudal margin & $\mathrm{CDM}$ & 32.5 & 32.3 \\
\hline Preventral caudal margin & CPV & 10.1 & 10.0 \\
\hline Total weight & TOW & $2840 \mathrm{gm}$ & $2750 \mathrm{gm}$ \\
\hline
\end{tabular}

vertical tiger-stripe markings were present, especially on the dorsal surface of body. Only the pectoral fins appeared uniformly dark. The bellies were yellowish white in colour. The teeth were similar in the upper and lower jaws, being typical cockscomb-shaped curved with heavy serrations and distal cusplets. The tooth count was 24 on the upper jaw and 21 on the lower jaw of both the male and female specimens.

Table 2 Stomach contents of tiger sharks, female and male, caught along the coasts of Libya

\begin{tabular}{ll}
\hline Female & Male \\
\hline - Cephalopod beak & - Pair of cephalopod beaks \\
- Semi digested cephalopod & - Semi digested cephalopod \\
- Semi digested fish $(9 \mathrm{~cm})$ probably & \\
Clupeiformes & \\
- Semi digested fish $(14 \mathrm{~cm})$ probably & \\
Mackerel & \\
\hline
\end{tabular}

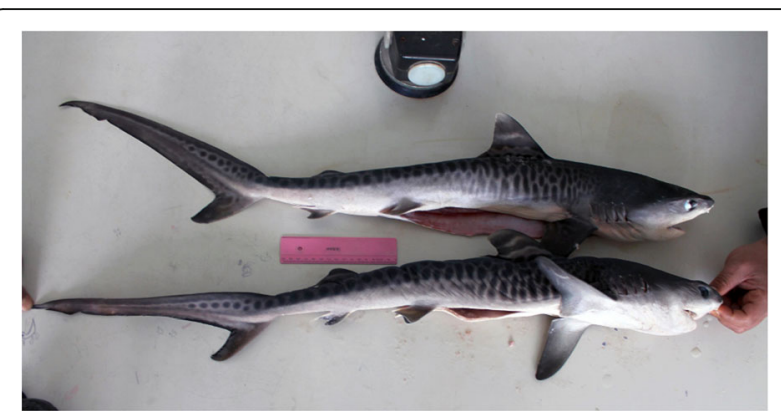

Fig. 2 Specimens of Galeocerdo cuvier caught in the Libyan coast. Male above, female below

Other morphometric measurements are reported in Table 1. The stomach contents of both the female and male specimens were not significant regarding to the possibility of recognizing any organisms present. Indeed, in both cases, the contents of the stomachs, cephalopods and fishes, were almost completely digested and difficult to determine at the species level (Table 2).

\section{Discussion}

The Mediterranean Sea has a long and complex history, which left traces in the actual status of its fauna and flora. After the opening of the Suez Canal and climate changes occurring at global and Mediterranean levels resulting in increased mean sea and surface temperatures, immigrant fauna and flora species, called lessepsian, moved into the Mediterranean from the Red Sea through the Suez Canal (Por, 1978). This phenomenon is still on-going. Continuous and important exchanges of marine organisms also occur at the Strait of Gibraltar between the Mediterranean Sea and the Atlantic Ocean. The Libyan coasts, positioned in the south of the Mediterranean, may be affected by immigration from both origins. This wide area is characterised by different habitats and topography.

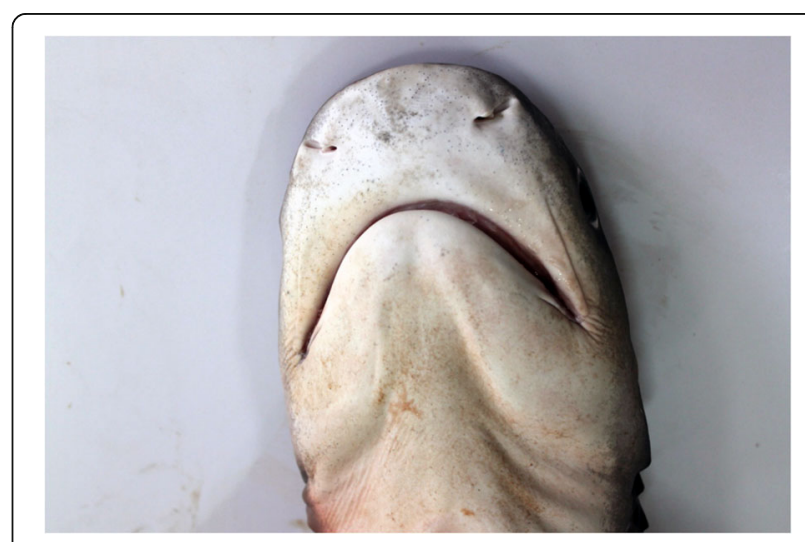

Fig. 3 Ventral view of the head of the male specimen of Galeocerdo cuvier caught in the Libyan coasts 
In the Mediterranean, many elasmobranch populations are now rare due to intense fishing activity, in which they are target or by-catch. Such fishing pressure has produced local extinctions or stock reductions of some elasmobranchs making certain fishing activities no longer economically viable (Ferretti et al., 2008). Such phenomena are less intense in the southern part of the basin, especially along the Libyan coasts. In fact, in this area, some artisanal fisheries using fixed gillnets, bottom set nets and drifting longlines still target cartilaginous fish such as Carcharhinidae, Lamnidae, Rhinobathos spp. and Squatina squatina (Lamboeuf, 2000). For this reason, the catch of some top predators such as the tiger shark near the coast is likely. Tiger sharks, especially juveniles, are taken as by-catch in many fisheries around the world, including those using longlines targeting swordfish and tuna, particularly those operating close to the continental shelves (Anderson, 1985; Berkeley \& Campos, 1988).

\section{Conclusions}

Our finding can be considered the first well-documented occurrence of G. cuvier in the southern Mediterranean. It confirms the sporadic occurrence of the species in the Mediterranean Sea. However this record cannot be taken as a proof of the stable occurrence of the species in the region or of a geographic extension of the species in to the Mediterranean Sea, even if, recently, $5 \mathrm{~nm}$ north of the Gorgona Island (North West Mediterranean), one of us has personally observed another specimen of about $2 \mathrm{~m}$ long, during a sportfishing on 29th of September 2015, unfortunately no photo was taken. As noted, the previous records led to doubts about the occurrence of tiger sharks in the Mediterranean basin (Serena, 2005) one from Malaga, Spain (Pinto de la Rosa, 1994) and the second from Sicily, Italy (Celona, 2000) were based only on the description of the jaws with no certified evidence of their provenance. The information in both publications is not accompanied by any photographic documentation of the whole individual and in one case (Pinto de la Rosa, 1994) the description was very limited.

Tiger sharks give birth generally along coastal areas at depths lower than $100 \mathrm{~m}$. The growth of young tiger sharks is quite rapid and they nearly double their size over the first year of life (Branstetter et al., 1987; Randall, 1992; Smith et al., 1998). Therefore, the specimens described here (male $95.8 \mathrm{~cm}$ and female $97.4 \mathrm{~cm}$ ) are likely to have been born recently in that area probably in the second part of 2014 and hence are assumed to be only a few months old. Juvenile tiger sharks are very slender with flexible bodies, swim with an inefficient motion and are very vulnerable to predators (Branstetter et al., 1987). It is unlikely that they were able to swim for very long distances as those needed to reach Libyan waters from either the Red Sea or the Atlantic. As a consequence, there are two possible alternative explanations for the finding of those two juvenile specimens. The first one is to hypothesize that the two pups were delivered from a resident female. Alternatively, these pups could have been delivered by a pregnant vagrant female. It has been reported that tiger sharks undertake trips of thousands of kilometres $(8,000 \mathrm{~km}$ in 99 days (Heithaus et al., 2007), or $1,800 \mathrm{~km}$ in 48 days (Holmes et al., 2014) and gestation periods of 12-16 months have been estimated (Clark \& von Schmidt, 1965). Therefore it is possible that mating could have happened outside the Mediterranean. Indeed, more compelling arguments are needed to support an enlargement of the distribution range and stable presence of the tiger shark in the Mediterranean waters.

Increased tropical influx through the Gibraltar Strait and the Suez Canal has resulted in the so-called "tropicalization" of the Mediterranean Sea (Bianchi \& Morri, 2003). Until the mid 20th century, alien species introduction, establishment, and expansion rates were low (Zenetos et al., 2008), mainly as a result of the water temperature and salinity barriers between the Red Sea and the Mediterranean Sea (Galil, 2006). The dispersal success and expansion of an invasive species depends upon many aspects after the suitability of the abiotic environment. The occasional specimens of tiger sharks recorded up to now are unable to support any real dispersal process linked to climate change.

\section{Acknowledgements \\ The data used for the present short note were obtained thanks to the collaboration of artisanal fishery fishermen of the Tripoli harbour. We are very grateful to the fishermen of the Tripoli harbour for their collaboration. Thanks also to Alvaro Juan Abella and Cecilia Mancusi (ARPAT, Italy) for the invaluable suggestions and for the revision of the text. Special thanks to the National Authority for Scientific Research of Libya for funding the project of invasive marine species in the Libyan coasts. Thanks also to Anassuya Ramachandran (Francis Crick Institute Limited, London, UK) and Ronan Russell (UCSF School of Medicine, San Francisco, USA) for reviewing the English language used in the text. Finally we want to thank the anonymous referees for suggesting appropriate changes which made the text more comprehensive.}

Authors' contributions

All authors read and approved the final manuscript.

Competing interests

The authors declare that they have no competing interests.

\section{Author details}

${ }^{1}$ Zoology Department, Tripoli University, Tripoli, Libya. ${ }^{2}$ Environmental Protection Agency-Tuscany Region (ARPAT), Tripoli, Italy. ${ }^{3}$ Institute for the Coastal Marine Environment (IAMC)-Italian National Research Council (CNR), Mazara, Italy.

Received: 9 September 2016 Accepted: 9 September 2016 Published online: 17 October 2016

\section{References}

Anderson ED. Analysis of various sources of pelagic shark catches in the northwest and western central Atlantic Ocean and Gulf of Mexico with comments on catches of other large pelagics. In: Shark catches from selected fisheries off the US East Coast. US East Coast: NOAA Technical Report NMFS; 1985. p. 1-14 
Bass AJ, D'Aubrey JD, Kistnasamy N. Sharks of the east coast of southern Africa. III. The families Carcharhinidae (excluding Mustelus and Carcharhinus) and Sphyrnidae. In: South African Association for Marine Biological Research. Oceanographic Research Institute. Investigational Reports. 1975.

Berkeley SA, Campos WL. Relative abundance and fishery potential of pelagic sharks along Florida's east coast. Mar Fish Rev. 1988:50:9-16.

Bianchi \& Morri. Global sea warming and "tropicalization" of the Mediterranean Sea: Biogeographic and ecological aspects. Biogeographia. 2003; 24: 319-327.

Bonfil R, Abdallah M. Field identification guide to the sharks and rays of the Red Sea and Gulf of Aden. In: FAO Species Identification Guide for Fishery Purposes. Rome: FAO; 2004. p. 71. 12 colour plates.

Bram JB, Page HM, Dugan JE. Spatial and temporal variability in early successional patterns of an invertebrate assemblage at an offshore oil platform. J. Exp. Mar. Bio. Ecol. 2005;317:223-237.

Branstetter S, Musick JA, Colvocoresses JA. A comparison of the age and growth of the tiger shark, Galeocerdo cuvieri, from off Virginia and from the northwestern Gulf of Mexico. NMFS. Fish Bull. 1987:85:269-79.

Celona A. First record of a tiger shark Galeocerdo cuvier (Peron and LeSueur, 1822) in the Italian waters Annales for Istrian and Mediterranean studies, Series. Hist Nat. 2000;2(21):207-10.

Clark E, von Schmidt K. Sharks of the central gulf coast of Florida. Bull. Mar. Sci. 1965;15:13-83.

Compagno LJV. Sharks of the World: An Annotated and Illustrated Catalogue of Shark Species Known to Date. Volume 4, Part 1. Hexanchiformes to Lamniformes. Rome: FAO; 1984.

Ebert DA, Fowler S, Compagno LJV, Dando M. Sharks of the world: a Fully Illustrated Guide. Plymouth: Wild Nature Press; 2013. p. 528.

Ebert DA, Stehmann MFW. Sharks, batoids, and chimaeras of the North Atlantic FAO Species Catalogue for Fishery Purposes. No. 7. Rome: FAO; 2013. p. 523.

Eschmeyer WN, Fricke R, van der Laan R. (eds) (2016) Catalog of fishes: Genera, Species, References. (http://researcharchive.calacademy.org/research/ ichthyology/catalog/fishcatmain.asp). Electronic version Accessed 16 Apr 2016.

Ferretti F, Myers RA, Serena F, Lotze HK. Loss of large predatory sharks from the Mediterranean Sea. Conservation Biology. 2008;22(4):952-964.

Fourmanoir P. Requins de la côte ouest de Madagascar. Ser. Oceanog. 1961;4:3-8.

Galil BS. Shipwrecked-shipping impacts on the biota of the Mediterranean Sea. In Davenport J.L. and Davenport J. (eds) The ecology of transportation: managing mobility for the environment. Dordrecht. The Netherlands: Springer-Verlag; 2006. p. 36-69.

Golani D, Orsi-Relini L, Massuti E, Quignad JP. CIESM Atlas of exotic species in the Mediterranean. Vol. 1. Fishes. In: Briand F, editor. CIESM. Publishers, Monaco. 2002. p. 256.

Jordan DS, Evermann BW. 1896. A check-list of the fishes and fish-like vertebrates of North and Middle America. Fish Comm. 5:207-584.

Heithaus MR, Frid A, Wirsing AJ, Dill LM, Fourqurean JW, Burkholder D, Thomson JA, Bejder L. State-dependent risk-taking by green sea turtles mediates topdown effects of tiger shark intimidation in a marine ecosystem Journal of Animal Ecology. 2007;76:837-844.

Holmes BJ, Pepperell JG, Griffiths SP, Jaine FRA, Tibbetts IR, et al. Tiger shark (Galeocerdo cuvier) movement patterns and habitat use determined $b$ satellite tagging in eastern Australian waters. Mar Biol. 2014;161:2645-2658.

Lamboeuf M. Artisanal fisheries in Libya. Census of fishing vessels and inventory of artisanal fishery metiers. FAO-COPEMED-MBRC. Final Report. 2000. p. 42.

Pinto de la Rosa FJ. Tiburones del mar de Alboran. Diputacion de Malaga: Servicio publicaciones Centro de Ediciones; 1994. p. 115

Por FD. Lessepsian migration. In: The influx of Red Sea biota into the Mediterranean by way of the Suez Canal. 23rd ed. Berlin: Ecological Studies Springer Verlag; 1978. p. 228.

Randall JE. Review of the biology of the tiger shark (Galeocerdo cuvier). Aust J Mar Freshwat Res. 1992:43:21-31.

Serena F. Field identification guide to the sharks and rays of the Mediterranean and Black Sea. Rome: Food and Agriculture Organization of the United Nations; 2005.

Serena F, Barone M, Mancusi C, Magnelli G, Vacchi M. The MEDLEM database application: a tool for storing and sarin the large sharks data collected in the Mediterranean countries. In: Basusta N, Keskin C, Serena F, Seret B, editors. The Proceedings of the Workshop on Mediterranean Cartilaginous Fish with Emphasis on Southern and Eastern Mediterranean. 23rd ed. Istanbul-Turkey: Turkish Marine Research Foundation; 2006. p. 118-27.
Simpfendorfer C. Biology of tiger sharks (Galeocerdo cuvier) caught by the Queensland shark meshing program off Townsville, Australia. Aust J Mar Freshwat Res. 1992:43:33-43.

Smith SE, Au DW, Show C. Intrinsic rebound potentials of 26 species of Pacific sharks. Mar Freshw Res. 1998;49:663-78.

Tester AL. Cooperative Shark Research and Control Program. Honolulu: University of Hawaii; 1969. Final Report.

Zenetos A, Meric E, Verlaque M, Galli P, Boudouresque C.-F, Giangrande A, Cinar E, Bilecenoglu M. Additions to the annotated list of marine alien biota in the Mediterranean with special emphasis on Foraminifera and Parasites. Mediterranean Marine Science. 2008;9:119-165.

\section{Submit your next manuscript to BioMed Central and we will help you at every step:}

- We accept pre-submission inquiries

- Our selector tool helps you to find the most relevant journal

- We provide round the clock customer support

- Convenient online submission

- Thorough peer review

- Inclusion in PubMed and all major indexing services

- Maximum visibility for your research

Submit your manuscript at www.biomedcentral.com/submit
Biomed Central 